\title{
Low ectomycorrhizal inoculum potential and diversity from soils in and near ancient forests of bristlecone pine (Pinus longaeva)
}

\author{
M.I. Bidartondo, J. Baar, and T.D. Bruns
}

\begin{abstract}
Intersite variation in ectomycorrhizal (ECM) inoculum potential in soils from 16 sites located in arid subalpine areas of the White Mountains of California was quantified. The study sites included valleys dominated by big sagebrush (Artemisia tridentata Nutt.) and mountainsides dominated by ancient Great Basin bristlecone pine (Pinus longaeva Bailey). ECM inoculum potential was not detected at three of four valley sites nor in $42 \%$ of forest soil samples. Only 10 mycorrhizal species were detected in bioassays, and four of those accounted for $94.5 \%$ of all colonized seedlings, in order of decreasing abundance these were Pyronemataceae sp., Rhizopogon sp., Wilcoxina rehmii Yang \& Korf, and Cenococcum sp. These species were identified also from in situ mycorrhizal roots. The abundance of the dominant Pyronemataceae sp. was significantly positively correlated with $\mathrm{pH}$, which at all forest sites was high compared with typical conifer forest soils. Our results show that the ECM inoculum potential of soils is low, homogeneous, and spatially restricted in these ancient high-elevation forests.
\end{abstract}

Key words: fungal community, molecular ecology, spore dispersal.

Résumé : Les auteurs ont quantifié la variation, entre les sites, du potentiel inoculant ectomycorhizien (ECM) de sols provenant de 16 sites isolés des régions subalpines des White Mountains, en Californie. Les sites d'étude incluent des vallées dominées par la grande armoise, Artemisia tridentata Nutt., et les flancs de montagnes dominées par le pin des anciens Great Basin, Pinus longaeva Bailey. Aucun inoculum ECM n'a été détecté sur trois des quatre sites des vallées, non plus que de $42 \%$ des échantillons de sols forestiers. On n'a retrouvé que 10 espèces mycorrhiziennes dans les bio-essais, et quatre de ces espèces colonisent à elles seules 94,5\% de tous les plants mycorhizés. Ce sont, en ordre décroissant d'abondance : une Pyronématacée sp., un Rhizopogon sp., le Wilcoxina rehmii Yang \& Korf, et un Cenococcum sp. Ces espèces ont également été identifiées à partir de racines mycorhizées récoltées in situ.

L'abondance de la Pyronématacée sp. est significativement et positivement corrélée avec le $\mathrm{pH}$, lequel sur tous les sites forestiers est élevé, comparativement aux sols typiques des forêts conifériennes. Les résultats indiquent que le potentiel ECM inoculant est faible, homogène, et spatialement restreint dans ces vieilles forêts de haute altitude.

Mots clés : communauté fongique, écologie moléculaire, dispersion des spores.

[Traduit par la Rédaction]

\section{Introduction}

The ancient Great Basin bristlecone pine (Pinus longaeva Bailey) has long generated interest among climatologists and plant ecologists (Ferguson 1968; LaMarche 1969; Hiebert and Hamrick 1984). Members of the Pinaceae are known to be obligately ectomycorrhizal (ECM), but the ECM fungal associates of bristlecone pine remain unstudied. In general, belowground diversity in cold environments, including that

Received June 28, 2000. Published on the NRC Research Press Web site on March 8, 2001.

M.I. Bidartondo ${ }^{1}$ and T.D. Bruns. Department of Environmental Science, Policy and Management, 111 Koshland Hall, University of California, Berkeley, CA 94720-3102, U.S.A.

J. Baar. Department of Aquatic Ecology and Environmental Biology, University of Nijmegen, 6525 ED Nijmegen, the Netherlands.

${ }^{1}$ Corresponding author (e-mail: martinb@nature.berkeley.edu). of mycorrhizal fungi, has been largely neglected (Gardes and Dahlberg 1996; Smith and Read 1997).

Pinus longaeva is the main subalpine tree of the dry, cold, and barren White Mountains of California. In this high desert range, the distribution of $P$. longaeva is complementary to that of big sagebrush (Artemisia tridentata Nutt.) (Wright and Mooney 1965). Although P. longaeva can occur in mixed stands with rare limber pine (Pinus flexilis James) and $A$. tridentata on more nutrient-rich sites, it is mostly found in scattered stands in harsh high-elevation sites where other plant species are absent (Wright and Mooney 1965; Beasley and Klemmedson 1980). Artemisia tridentata, an arbuscular mycorrhiza-dependent shrub, is dominant in all non-forested subalpine areas.

The high frequency of stem clumps observed in ancient bristlecone pine stands indicates that establishment of these winged-seeded conifers is actually mediated by seed-caching nutcrackers (Nucifaga spp., Corvidae) particularly at highelevation sites (Lanner 1988; Torick et al. 1996). In contrast, the Colorado bristlecone pine (Pinus aristata Bailey), the closest relative of $P$. longaeva, is a shade-intolerant pioneer 
species that regenerates following fires, with fire intervals of a thousand or more years (Baker 1992). Regardless of the specific mechanisms for seed dispersal, conifer seedling performance in nature is affected by ECM inoculum availability (Read 1998; Horton et al. 1999).

Both ECM inoculum and diversity appear to increase with time along primary and secondary successional chronosequences, but they remain spatially uneven (Visser 1995; Boerner et al. 1996; Helm et al. 1996). For instance, establishment may be sporadic and limited to forest edges (Boerner et al. 1996) or places close to an inoculum source. The patchy nature of ECM inoculum may interact with seed dispersal and competition between seedlings of ECMdependent species and established individuals of arbuscular mycorrhizae dependent species. This can ultimately regulate the rate and spatial pattern of ECM-dependent species establishment (Boerner et al. 1996).

How the complementary distribution of $P$. longaeva and A. tridentata interacts with ECM community structure across soil types is not known. To begin to address this question, we used $P$. longaeva seedling bioassays to quantify intersite variation in ECM inoculum potential of soils among 16 sites at the White Mountains. We examined whether ECM inoculum potential differs $(i)$ among $P$. longaeva forest patches because of substrate type and (ii) between forests and valleys. We predicted that ECM inoculum reflects mycorrhizal adaptation to substrate type and that there is limited ECM inoculum dispersal from mountainside $P$. longaeva forests to valleys of $A$. tridentata. If either were true, mycorrhizal inoculum can reinforce the spatial patterning characteristic of $P$. longaeva and A. tridentata communities.

\section{Materials and methods}

\section{Study areas}

In July 1997, sixteen sites were chosen for this study, of which 12 were located in different forested mountainsides dominated by Great Basin bristlecone pine (Pinus longaeva Bailey, Pinaceae), with scattered limber pine (Pinus flexilis James), big sagebrush (Artemisia tridentata Nutt., Compositae), lupine (Lupinus sp., Leguminosae), buckwheat (Eriogonum spp., Polygonaceae), and bluegrass (Poa spp., Poaceae). Four sites were located in different treeless valleys $(\mathrm{V})$, dominated by $A$. tridentata with scattered Lupinus spp., in concave positions between forested mountainsides. All sites were located within the Ancient Bristlecone Pine Forest of the Mount Barcroft-Blanco Mountain Area, Inyo National Forest, southeastern California, U.S.A. (Fig. 1), and all stands of $P$. longaeva were approximately 1000 years old. This area is in cold uplands, where the mean annual precipitation is $23 \mathrm{~cm}$ and the mean annual temperature is $1^{\circ} \mathrm{C}$. The soils are Cryoborolls on colluvial and alluvial positions on mountains at elevations from 2800 to $3500 \mathrm{~m}$. Of the 12 forest sites, four were dolomite (D) outcrops (light gray to white calcareous rock), four were sandstone (S) outcrops of the Campito Formation (greenish to brownish primarily quartzitic sandstone), and four were granitic (G) outcrops (medium gray monzonite - diorite granites). These were the three geologic substrates examined in detail by Wright and Mooney (1965), who first studied the complementary distributions of $P$. longaeva and A. tridentata in this area. The trees are widely spaced, surrounded by their own litter shadow and separated from neighboring trees by little or no vegetation amidst the gravel and bare rock. This pattern is most pronounced at D sites where conditions are the most arid, $P$. flexilis and A. tridentata are
Fig. 1. Location of study sites (solid squares) within the Ancient Bristlecone Pine Forest and within California. S, sandstone; D, dolomite; G, granite; V, valley.

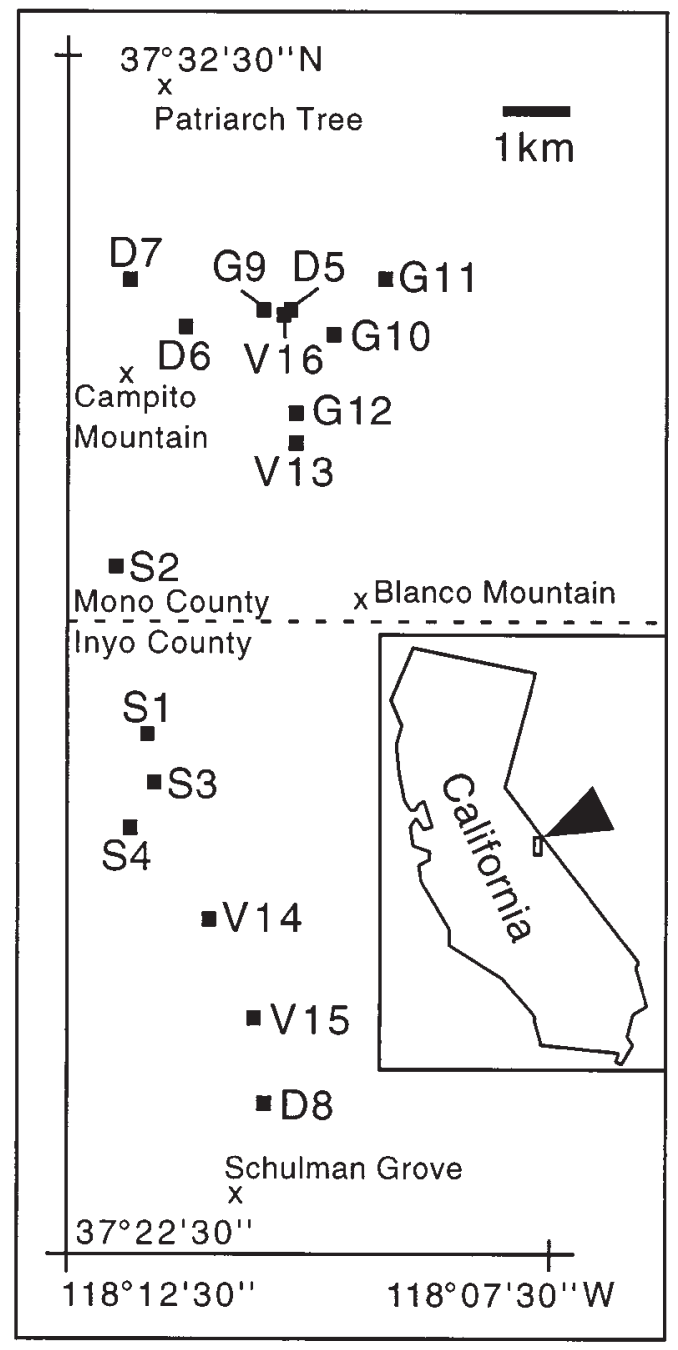

absent, the spread of fire from lightning is most unlikely, and pure stands of $P$. longaeva can reach their greatest age (up to 4700 years) (Billings and Thompson 1957).

\section{Sampling design}

In this study there were 16 study sites $\times 1$ sampling area $\times 4$ sampling plots $\times 4$ soil samples $=256$ soil samples. In each of the 16 study sites (Fig. 1), one square sampling area of $20 \times 20 \mathrm{~m}$ was established. In the 12 forested sites, each of these areas was chosen to have at each edge one mature $P$. longaeva and to be at least $20 \mathrm{~m}$ away from the edge to the nearest $P$. flexilis (present only at $\mathrm{S}$ and $\mathrm{G}$ sites). Within each $20 \times 20 \mathrm{~m}$ area, four sampling plots were chosen on a tree-biased fashion, since the litter shadows of each tree represented the only comparatively mesic areas at the sites. At $\mathrm{V}$ sites, a similar procedure was followed, but the sampling plots were located at each corner of the sampling area. All study sites were located with a global positioning system (GPS) Pathfinder Basic ${ }^{+}$(Trimble, Sunnyvale, Calif.), and the distance from $\mathrm{V}$ sites to the nearest forest edge was estimated in situ and checked with topographic maps. At each sampling plot, four samples of approximately $0.2 \mathrm{~L}$ of soil were collected with a hand trowel from among the rocks and gravel from points chosen at random within a $1-\mathrm{m}^{2}$ area adjacent to the tree trunk and sealed in- 
dividually in plastic bags. To prevent cross contamination, the trowel used for sampling was rinsed with dilute sodium hypochlorite between sampling plots. At site D7 we also removed five soil cores (4.6 cm diameter, $15-25 \mathrm{~cm}$ depth) at arbitrary locations within the sampling area to estimate in situ ectomycorrhizal diversity. Unfortunately, because of the abundance of rocks, soil coring was not possible at other sites. Care was taken to minimize disruption in the areas sampled. All soil samples and soil cores were transported to the laboratory under refrigeration.

\section{Mycorrhizal inoculum potential}

Pinus longaeva seeds, obtained from the USDA Forest Service Nursery, Placerville, Calif., were surface sterilized in 30\% hydrogen peroxide for $30 \mathrm{~min}$ and planted in Cone-tainer pots (RLC-4 Pine Cell, $2.5 \times 16 \mathrm{~cm}$; Stuewe and Sons, Corvallis, Oreg.) filled with the contents of each soil sample. Within 4 days after field collection, one seed was planted in each soil pot. Seeds were handled aseptically to avoid cross contamination during planting. In addition, 20 pots were filled with soil from randomly selected soil samples (approximately $90 \mathrm{~mL}$ ) and steam-sterilized for $2 \mathrm{~h}$ twice with a 2-day interval between sterilizations. These were planted as controls to assay for laboratory contamination. The seeds had over $90 \%$ germination rate, and for those that failed to germinate, a second seed was planted 10 days after the first planting. Seedlings that died after the second planting were not replaced. Pots were maintained under fluorescent lights in the laboratory, isolated with plastic sheets to prevent airborne spore contamination, and watered twice weekly with tap water. Ten months after planting, the 236 surviving seedlings (217 from the 256 field samples and 19 from 20 controls) were harvested within a 1-month period. By then, the root systems were densely branched, they strongly maintained the soil structure when removed from the pots, and taproots were emerging from the bottom. Each root system was washed by spraying with water and examined using a dissecting microscope to sample all the morphological types of live mycorrhizal root tips present in each seedling. The mycorrhizal root tip types were subsequently preserved by lyophilization.

The soil cores were examined by placing each in a $500 \mu \mathrm{m}$ opening sieve and spraying with water. All the washed soil and roots were then spread thinly in Petri dishes and examined using dissecting scopes, sorted into morphotypes for each core, and lyophilized.

\section{Molecular identification}

ECM fungi were identified using methods described by Gardes and Bruns (1996). Briefly, we extracted DNA from individual ECM roots of each morphotype, and we amplified the internal transcribed spacer (ITS) of the nuclear ribosomal repeat by the polymerase chain reaction (PCR) with the fungal-specific primers ITS1F and ITS4 (White et al. 1990; Gardes and Bruns 1993). PCR products were then screened by restriction fragment length polymorphisms (RFLP) using the restriction endonucleases AluI and HinfI (New England Biolabs Inc., Beverly, Mass.). We estimated the molecular size of the restriction fragments using GelReader version 2.0.5 (National Center for Supercomputing Applications, Champaign, Ill.) and sorted the morphotype fragment sizes in various combinations to identify groups of morphotypes that matched for both restriction endonucleases. We checked that matching ITS-RFLP types were compatible with our morphotype descriptions of their gross morphology.

The phylogenetic distribution of the most frequent ITS-RFLP types obtained was also examined. Because herbarium collections of ectomycorrhizal fungal sporocarps from the area were not available and we did not find any sporocarps while field sampling, direct ITS-RFLP matching to fungal sporocarps was not possible. Instead, we used PCR amplification and sequencing of one or more of the following fungal rDNA regions: $(i)$ a fragment of the mitochondrial large subunit (mtLSU) (Bruns et al. 1998), (ii) the 5' end of the 28S nuclear gene between primers ctb6 (GCATATCAATAAGCGGAGG) and tw14 (GAAGTTTCCCTCAGGATAGC), and (iii) the ITS+5.8S nuclear genes. Sequencing of both strands was performed with an ABI model 377 sequencer (Applied Biosystems Co., Foster City, Calif.) using an ABI prism dye terminator cycle sequencing core kit (Perkin Elmer Co., Foster City, Calif.) or a Thermo Sequenase dye terminator cycle sequencing premix kit (Amersham Pharmacia Biotech, Piscataway, N.J.). We used DNA Sequencing Analysis version 2.1.2 and Sequence Navigator version 1.0.1 (Applied Biosystems Co., Foster City, Calif.) software for processing raw data. Sequences from the mtLSU were manually aligned to the data base of Bruns et al. (1998). Sequences from the $28 \mathrm{~S}$ and ITS+5.8S genes were used to query the GenBank data base via the basic local alignment search tool (BLAST). The nearest relatives of each mycorrhizal type were downloaded, aligned using CLUSTAL X (Windows interface for CLUSTAL W; Thompson et al. 1994), and the alignment checked manually. To infer relationships, we used the neighbor-joining algorithm implemented in the program PAUP, version beta 4a (Swofford 2000).

\section{Soil parameters}

The soil $\mathrm{pH}$ and organic matter on samples from all plots was measured. Three grams of fresh soil per sample plot (pooled from the four soil samples taken at each plot) were placed in a $125-\mathrm{mL}$ beaker to which we added $37.5 \mathrm{~mL}$ of double distilled water $\left(\mathrm{ddH}_{2} \mathrm{O}\right)$ to obtain a $1: 12.5(\mathrm{w} / \mathrm{v})$ soil- $\mathrm{ddH}_{2} \mathrm{O}$ dilution as recommended for calcareous soils by Nilsson et al. (1995). The soil and water were shaken for $2 \mathrm{~h}$, left to settle overnight, and the $\mathrm{pH}$ in $\mathrm{H}_{2} \mathrm{O}\left(\mathrm{pH}_{\mathrm{w}}\right)$ determined using a Corning $\mathrm{pH}$ Meter 220 (Corning Instruments, Corning, N.Y.). Then, $2.8 \mathrm{~g}$ of $\mathrm{KCl}$ were added and the procedure repeated to determine $\mathrm{pH}$ in salt solution $\left(\mathrm{pH}_{\mathrm{K}}\right)$. To estimate organic matter content, percent loss on ignition (\%LOI) was determined at $360^{\circ} \mathrm{C}$ for $1-2 \mathrm{~g}$ of each soil sample. The \%LOI was converted to standard Walkley-Black percent soil organic matter $(\% \mathrm{OM})$ using the equation: $\% \mathrm{OM}=\% \mathrm{LOI}-0.30$ (Sims and Heckendorn 1991).

\section{Data analysis}

Because $\mathrm{pH}$ and \%OM had significantly unequal variances, we $\log$ transformed the data and used Kruskal-Wallis tests and TukeyKramer honestly significant difference tests for comparing $\mathrm{pH}$ and $\% \mathrm{OM}$ among sites and between pairs of sites, respectively. We also tested the ability of $\mathrm{pH}$ and $\% \mathrm{OM}$ to predict the abundance of mycorrhizal types using nominal logistic regressions between the soil parameters and each mycorrhizal type across all sites. For statistical tests, we used JMP (SAS Institute Inc., Cary, N.C.).

The dissimilarity among sites was calculated in terms of the composition of their mycorrhizal assemblages using the BrayCurtis distance measure (Bray and Curtis 1957), which is a robust measure of the ecological distance between sites (Faith et al. 1987). The distance between two sites was calculated using the site counts of mycorrhizal seedlings of each mycorrhizal type as follows: $\left(\sum_{k}\left|X_{i k}-X_{j k}\right|\right) /\left(\sum_{k} X_{i k}+X_{j k}\right)$ where $X_{i k}$ is the abundance of the $k$ th mycorrhizal type at site $i$, and $X_{j k}$ is the abundance of the $k$ th mycorrhizal type at site $j$. Sites supporting identical assemblages have a dissimilarity of 0 , and sites with no shared types have a dissimilarity of 1 . We used the counts of mycorrhizal types that were detected in more than one seedling (Pyronemataceae sp. Rhizopogon sp., Wilcoxina rehmii Yang \& Korf, and Cenococcum sp.). The sites were then clustered on the basis of the site by site dissimilarity matrix of their mycorrhizal assemblages by neighborjoining using PHYLIP (Felsenstein 1981) and cluster support was assessed with 1000 bootstrap runs. 
Table 1. GenBank sequence accession numbers or restriction fragment sizes for eight identified mycorrhizal taxa of Pinus longaeva detected in situ at site D7 including four taxa detected in more than one seedling in bioassays from all sites.

\begin{tabular}{|c|c|c|c|c|}
\hline Taxon & Bioassay & nr28S & mtLSU & nrITS \\
\hline Pyronemataceae sp. & Yes & AF266709 & & AF266709 \\
\hline Rhizopogon sp. & Yes & AF266705 & & AF266710 \\
\hline Wilcoxina rehmii & Yes & AF266708 & & AF266708 \\
\hline Cenococcum sp. & Yes & & & $\begin{array}{l}\text { AluI: } 380,182 \\
\text { HinfI: } 148,110\end{array}$ \\
\hline Tricholomatoid sp. & No & & AF266703 & $\begin{array}{l}\text { AluI: } 500,123 \\
\text { HinfI: } 282,225,116\end{array}$ \\
\hline Thelephoroid sp. & No & & AF266702 & $\begin{array}{l}\text { AluI: } 235,112,92,89 \\
\text { HinfI: } 372,151\end{array}$ \\
\hline Suilloid sp. & No & & AF266704 & $\begin{array}{l}\text { AluI: } 436,209 \\
\text { HinfI: } 250,116,105,100\end{array}$ \\
\hline Cortinarioid sp. & No & AF266711 & & $\begin{array}{l}\text { AluI: } 574,111,89 \\
\text { HinfI: } 320,250,106,101\end{array}$ \\
\hline
\end{tabular}

Note: Six additional unidentified mycorrhizal taxa were detected in single bioassay seedlings (not listed).

\section{Results}

\section{Mycorrhizal community}

The four mycorrhizal taxa from bioassays identified in this study are listed in Table 1. Four additional taxa identified from roots at site D7 but not detected in bioassays are also listed in Table 1. Six additional mycorrhizal types that were present only in single bioassay seedlings $(5.5 \%$ of all mycorrhizal seedlings) were not identified further or included in our analyses. The dominant mycorrhizal taxon across seedling bioassays from forest sites shows weak ITS and 28S sequence similarity to Pezizales species (Ascomycota) available in GenBank. It is likely to represent a novel mycorrhizal lineage within the family Pyronemataceae (see Landvik et al. 1997) of the order Pezizales based on comparing its ITS sequence to Sphaerosporella, Scutellinia, Tricharina, Geopyxis, Tarzetta, Pyropyxis, Rhizina, and other Pezizalean and Helotialean genera ( $\mathrm{T}$. Schumacher, University of Oslo, Oslo, Norway, personal communication) and its $28 \mathrm{~S}$ sequence to members of Pezizaceae (51 species), Ascobolus, Verpa, and Pyronemataceae (Aleurina, Otidea, Smardaea, Marcelleina) (K. Hansen, University of Copenhagen, Copenhagen, Denmark, personal communication). For the purposes of this study, we labeled it "Pyronemataceae sp." Another recurring mycorrhizal taxon in the bioassays produced an ITS sequence that differs from $W$. rehmii (GenBank accession U38565) by only one transition (K.N. Egger, personal communication); thus, we labeled it W. rehmii. A Rhizopogon sp. (Rhizopogonaceae, Basidiomycota) ITS sequence from the bioassays was found to be most closely related to Rhizopogon section Rhizopogon (L. Grubisha, University of California, Berkeley, personal communication; Grubisha 1998). The final taxon to be detected in the bioassays was Cenococcum sp. (Loculoascomycetes, Ascomycota), which is distinguished morphologically by black, club-shaped mycorrhizas and thick emanating hyphae. All control seedlings appeared non-mycorrhizal; they showed abundant root hairs and no hyphal mantles. This criterion was consistent with negative ITS1F-ITS4 PCR amplification from roots of a subset of seedlings grown in fresh soil $(n=15)$ that were classified as non-mycorrhizal because of root morphology.

\section{Mycorrhizal community and soil parameters}

A nominal logistic regression model with $\mathrm{pH}_{\mathrm{K}}$ as a factor and Pyronemataceae sp. as a response had a significant likelihood ratio chi-square $\left(p<0.0001, r^{2}=0.19\right)$, although the percentage of variation explained was low. The $\mathrm{pH}_{\mathrm{w}}$ behaved similarly. The $\mathrm{pH}_{\mathrm{K}}$ accurately predicted the presence of Pyronemataceae sp. in approximately $20 \%$ of the 64 sample plots, while the standard correlation between Pyronemataceae sp., and $\mathrm{pH}_{\mathrm{w}}$ was $63 \%$.

The Kruskal-Wallis tests indicated that $\mathrm{pH}_{\mathrm{w}}, \mathrm{pH}_{\mathrm{K}}$, and $\%$ OM were significantly different among sites $(p<0.0001$, 0.0001 , and 0.0006 , respectively). The Tukey-Kramer tests indicated that $\mathrm{pH}_{\mathrm{w}}$ and $\mathrm{pH}_{\mathrm{K}}$ were significantly higher at the D sites compared with all other sites and that $\mathrm{pH}_{\mathrm{K}}$ was significantly higher at the $\mathrm{G}$ sites than at the $\mathrm{V}$ sites.

As shown in Table 2, three of the four $\mathrm{V}$ sites were devoid of mycorrhizal inoculum potential in our assay. Site V16 represents the only exception; it yielded a higher percentage of seedlings colonized by Rhizopogon sp. than any forest. Rhizopogon sp. was the only source of mycorrhizal inoculum detected at V16. Site V16 was located on a saddle approximately $30 \mathrm{~m}$ away from trees growing on dolomitic soil and $100 \mathrm{~m}$ away from trees growing on granitic soil. All other V sites were at least $300 \mathrm{~m}$ away from the nearest trees.

Clustering based on Bray-Curtis distances placed all valley sites (except V16, which was an outlier) together with two sandstone sites to the exclusion of all dolomite, all granite, and two other sandstone sites, which formed another cluster. Bootstrap support greater than 50\% was not observed for any cluster (data not shown) because of the high similarity observed across sites.

\section{Discussion}

The inoculum potential and species richness documented in this study are dramatically lower than those previously reported from coastal California Pinus muricata D. Don forest 


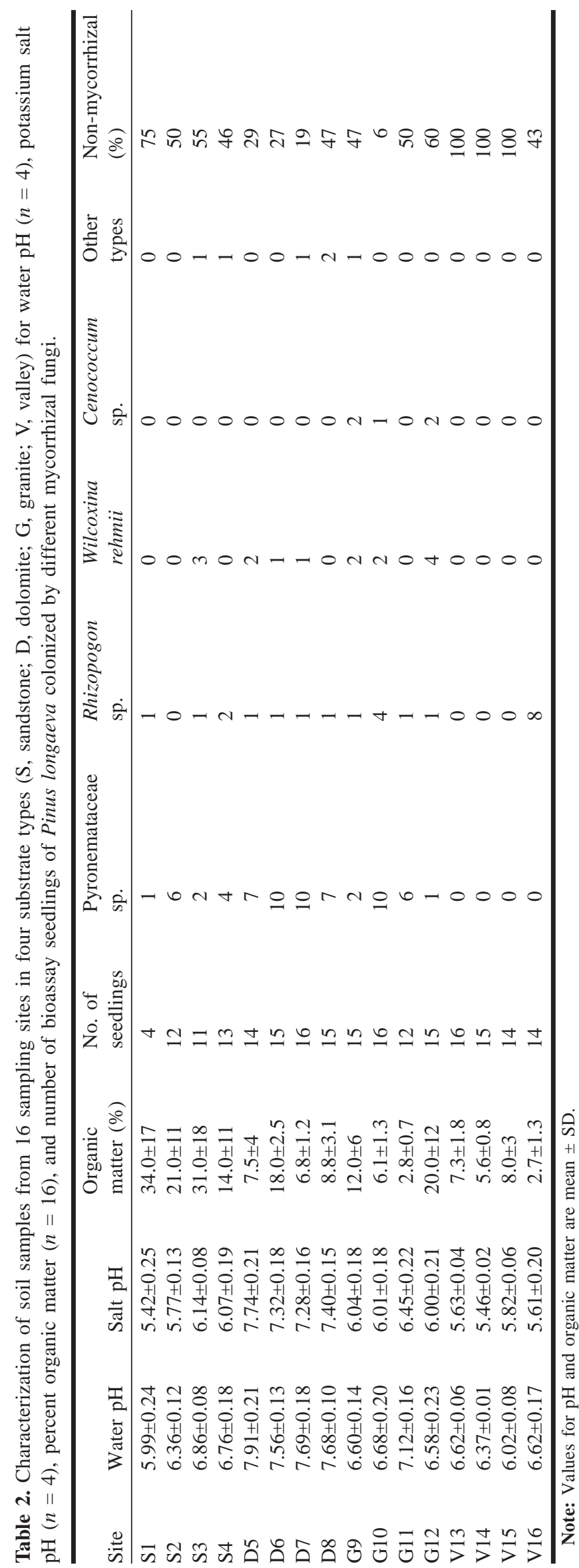

soils. Taylor and Bruns (1999) reported that 15 soil cores from a single 40-year-old $P$. muricata site produced 37 mycorrhizal types in bioassays and 4 (5.3\%) nonmycorrhizal seedlings. Furthermore, only one $(1.4 \%)$ nonmycorrhizal seedling was found among 70 seedlings planted in soil from nine soil cores removed in a $P$. muricata forest following a stand-replacing wildfire (M.I. Bidartondo, unpublished data). While the bioassay inoculum potential of forest soil does not reflect in situ inoculum exactly, both measures can show similar patterns (Baar et al. 1999). Thus, we infer that the mycorrhizal community associated with ancient $P$. longaeva at the White Mountains has produced a very poorly developed mycorrhizal inoculum bank that is largely dominated by a Pyronemataceae sp. (Ascomycota). Our sixty-four soil samples from 16 different sites produced only 10 mycorrhizal types in bioassays and 67 (42\%) of 158 surviving seedlings were non-mycorrhizal when planted in fresh forest soil. Most of the fungi we retrieved from bioassays belong to groups that are also common during the first growing seasons following forest fires (Baar et al. 1999).

We hypothesize that the divergent inoculum soil banks of $P$. longaeva and P. muricata are due to climatic differences between both biomes, because fungal sporocarp production is strongly controlled by climatic factors (Petersen 1977; Vogt et al. 1992). Temperate coastal forests are well known to support a diverse and voluminous annual mycorrhizal sporocarp production, while sporocarp production in arid subalpine forests may be negligible or altogether absent in most years because of drought and nightly freezing during the short summer season.

The consistent presence of Pyronemataceae sp. mycorrhizal inoculum in soils from all forest sites is quite notable. Within single conifer forest stands, highly spatially variable mycorrhizal assemblages have been reported (Gardes and Bruns 1996; Baar et al. 1999; Taylor and Bruns 1999; Stendell et al. 1999), and this is apparently reflected in uneven localized inoculum distributions (Baar et al. 1999; Taylor and Bruns 1999). Conifer forest soils are typically acidic ( $\mathrm{pH}$ 4.0-6.5; Barnes et al. 1998), but the cold, dry, and comparatively alkaline soils of the White Mountains' forests ( $\mathrm{pH}$ 6-7.9) may lead to more uniform ectomycorrhizal communities that allow conifers to obtain nutrients from such environments. Our data provide evidence for a weak positive correlation between the abundance of Pyronemataceae sp. inoculum and soil $\mathrm{pH}$. This may reflect adaptation of this fungus to relatively alkaline soils. Nonetheless, this study suggests weak overall mycorrhizal inoculum structuring according to substrate type or site among the forest sites examined. Rhizopogon sp. was widespread but considerably less common and abundant than Pyronemataceae sp. This may reflect the distribution of the field inoculum of Rhizopogon sp. or its poor competitive ability relative to Pyronemataceae sp. in bioassays.

The absence of the Ascomycete fungi Pyronemataceae sp., W. rehmii, and Cenococcum sp. in all four valley sites suggests that these species have a very limited ability to disperse outside forest edges. These fungi produce asexual chlamydospores or sclerotia in the soil, which are expected to undergo little if any dispersal, instead relying on contact with growing host root tips. Most Pezizales species, perhaps including this study's Pyronemataceae sp., can also produce 
airborne ascospores on epigeous cup-shaped ascocarps, but production of these would be limited to rare periods of high humidity. Fewer Pezizales species produce hypogeous ascocarps. The Basidiomycete Rhizopogon sp. may have a higher ability to escape the forest edge (as indicated by its comparatively high incidence on site V16) by producing sexual basidiospores, but it was not found in valley sites over $300 \mathrm{~m}$ from forest edges. This is explicable by the basidiocarp production and dispersal behavior of Rhizopogon. Its underground basidiocarps may be less sensitive to short drying and freezing events, and its small-mammal-dispersed basidiospores should most effectively disperse over short distances (Molina et al. 1999). In the case of P. muricata, Cenococcum spp. (which produces only asexual soil-borne sclerotia) mycorrhizal inoculum potential could not be detected at 5 and $35 \mathrm{~m}$ from the forest edge in an arbuscular mycorrhizal plant community, while Rhizopogon spp. inoculum was equally abundant within the edge of the forest as $35 \mathrm{~m}$ away from it after a stand-replacing wildfire (M.I. Bidartondo, unpublished data). Cenococcum sp. was found to be common in conifer roots at tree line and on exposed glacial moraines in the Oregon Cascades (Trappe 1988). The dispersal range of Rhizopogon below $300 \mathrm{~m}$ away from $P$. longaeva forest edges remains to be tested, but we predict that it is spatially patchy and quite restricted.

This is the first systematic study of the mycorrhizal community of a high-elevation species, and it suggests that, under harsh environmental conditions, the mycorrhizal community is severely limited in its development. Despite the great age of $P$. longaeva forests, we have shown overall low diversity and strict spatial constraints associated with ectomycorrhizal inoculum potential in the White Mountains. These are likely results of the cold arid environment in which $P$. longaeva grows. A limited mycorrhizal inoculum could interact with seed dispersal and competition with $A$. tridentata to produce and reinforce the landscape-level distribution observed for $P$. longaeva. Future studies of in situ mycorrhizal diversity and mycorrhizal inoculum adjacent to forest edges have the potential to show mycorrhizalmediated limitations imposed on $P$. longaeva distribution by both substrate and competition.

\section{Acknowledgments}

We thank Tim Szaro for computer assistance; Carla D'Antonio and two anonymous reviewers for comments on the manuscript; Paddy Hardy for sampling permits; Elizabeth Phillips for logistical assistance; Lisa Bryant for soils information; Keith Egger, Trond Schumacher, Karen Hansen, and Lisa Grubisha for access to unpublished sequence data; Ron Amundson for soil analysis equipment; and the staff at Crooked Creek Research Station for their cooperation. Funding was provided by a White Mountains Research Station Graduate Research Fellowship to M.I.B., and National Science Foundation grant No. DEB9628852 to T.D.B.

\section{References}

Baar, J., Horton, T.R., Kretzer, A.M., and Bruns, T.D. 1999. Mycorrhizal colonization of Pinus muricata from resistant propagules after a stand-replacing wildfire. New Phytol. 143: 409-418.

Baker, W.L. 1992. Structure, disturbance and change in the bristlecone pine forests of Colorado, USA. Arct. Alp. Res. 24: 17-26.

Barnes, B.V., Zak, D.R., Denton, S.R., and Spurr, S.H. 1998. Forest ecology. 4th ed. John Wiley \& Sons, New York.

Beasley, R.S., and Klemmedson, J.O. 1980. Ecological relationships of bristlecone pine. Am. Midl. Nat. 104: 242-252.

Billings, W.D., and Thompson, J.H. 1957. Composition of a stand of old bristlecone pines in the White Mountains of California. Ecology, 38: 158-160.

Boerner, R.E.J., Demars, B.G., and Leicht, P.N. 1996. Spatial patterns of mycorrhizal infectiveness of soils along a successional chronosequence. Mycorrhiza, 6: 79-90.

Bray, J.R., and Curtis, J.T. 1957. An ordination of the upland forest communities of southern Wisconsin. Ecol. Monogr. 27: 325-349.

Bruns, T.D., Szaro, T.M., Gardes, M., Cullings, K.W., Pan, J.J., Taylor, D.L., Horton, T.R., Kretzer, A., Garbelotto, M., and Li, Y. 1998. A sequence database for the identification of ectomycorrhizal basidiomycetes by phylogenetic analysis. Mol. Ecol. 7: 257-272.

Faith, D.P., Minchin, P.R., and Belbin, L. 1987. Compositional dissimilarity as a robust measure of ecological distance. Vegetatio, 69: $57-68$.

Felsenstein, J. 1981. Phylogeny inference package (PHYLIP), version 3.5 edition. University of Washington, Seattle.

Ferguson, C.W. 1968. Bristlecone pine: science and aesthetics. Science (Washington, D.C.), 159: 839-846.

Gardes, M., and Bruns, T.D. 1993. ITS primers with enhanced specificity for basidiomycetes: application to the identification of mycorrhizae and rusts. Mol. Ecol. 2: 113-118.

Gardes, M., and Bruns, T.D. 1996. Community structure of ectomycorrhizal fungi in a Pinus muricata forest: above- and below-ground views. Can. J. Bot. 74: 1572-1583.

Gardes, M., and Dahlberg, A. 1996. Mycorrhizal diversity in arctic and alpine tundra: an open question. New Phytol. 133: 147-157.

Grubisha, L.C. 1998. Systematics of the genus Rhizopogon inferred from nuclear ribosomal DNA large subunit and internal transcribed spacer sequences. M.S. thesis, Department of Botany and Plant Pathology, Oregon State University, Corvallis.

Hiebert, R.D., and Hamrick, J.L. 1984. An ecological study of bristlecone pine (Pinus longaeva) in Utah and Eastern Nevada. Great Basin Nat. 44: 487-494.

Helm, D.J., Allen, E.B., and Trappe, J.M. 1996. Mycorrhizal chronosequence near Exit Glacier, Alaska. Can. J. Bot. 74: 1496-1506.

Horton, T.R., Bruns, T.D., and Parker, V.T. 1999. Ectomycorrhizal fungi associated with Arctostaphylos contribute to Pseudotsuga menziesii establishment. Can. J. Bot. 77: 93-102.

LaMarche, V.C. 1969. Environment in relation to age of bristlecone pines. Ecology, 50: 53-59.

Landvik, S., Egger, K.N., and Schumacher, T. 1997. Towards a subordinal classification of the Pezizales (Ascomycota): phylogenetic analyses of SSU rDNA sequences. Nord. J. Bot. 17: 403-418.

Lanner, R.M. 1988. Dependence of Great Basin bristlecone pine on Clark's nutcracker for regeneration at high elevations. Arct. Alp. Res. 20: 358-362.

Molina, R., Trappe, J.M., Grubisha, L.C., and Spatafora, J.W. 1999. Rhizopogon. In Ectomycorrhizal fungi: key genera in profile. Edited by W.G. Cairney, and S.M. Chambers. SpringerVerlag, Berlin. pp. 129-161.

Nilsson, T., Kranz-Eliasson, B., and Bjurman, M. 1995. Measurement of $\mathrm{pH}$ in soil samples from a cutover peatland in Sweden: the effect of electrolyte and solution/soil ratio. Commun. Soil Sci. Plant Anal. 26: 361-374. 
Petersen, P.M. 1977. Investigations on the ecology and phenology of the macromycetes in the Arctic. Medd. Gronl. 199: 1-72.

Read, D.J. 1998. The mycorrhizal status of Pinus. In Ecology and biogeography of Pinus. Edited by D.M. Richardson. Cambridge University Press, New York.

Sims, J.T., and Heckendorn, S.E. 1991. Methods of soil analysis. Agricultural Experiment Station, University of Delaware, Newark. Coop. Bull. No. 10.

Smith, S.E., and Read, D.J. 1997. Mycorrhizal symbiosis. 2nd ed. Academic Press, San Diego, Calif.

Stendell, E.R., Horton, T.R., and Bruns, T.D. 1999. Early effects of prescribed fire on the structure of the ectomycorrhizal fungus community in a Sierra Nevada ponderosa pine forest. Mycol. Res. 103: 1353-1359.

Swofford, D.L. 2000. PAUP: phylogenetic analysis using parsimony, version beta 4a edition. Sinauer Associates, Sunderland, Mass.

Taylor, D.L., and Bruns, T.D. 1999. Community structure of ectomycorrhizal fungi in a Pinus muricata forest: minimal overlap between the mature forest and resistant propagule communities. Mol. Ecol. 8: 1837-1850.

Thompson, J.D., Higgins, D.G., and Gibson, T.J. 1994. CLUSTAL W: improving the sensitivity of progressive multiple sequence align- ment through sequence weighting, positions-specific gap penalties and weight matrix choice. Nucleic Acids Res. 22: 4673-4680.

Torick, L.L., Tomaback, D.F., and Espinoza, R. 1996. Occurrence of multi-genet tree clusters in "wind-dispersed" pines. Am. Midl. Nat. 136: 262-266.

Trappe, J.M. 1988. Lessons from alpine fungi. Mycologia, 80: 1-10.

Visser, S. 1995. Ectomycorrhizal fungal succession in jack pine stands following wildfire. New Phytol. 129: 389-401.

Vogt, K., Bloomfield, J., Ammirati, J.F., and Ammirati, S.R. 1992. Sporocarp production by basidiomycetes, with emphasis on forest ecosystems. In The fungal community: its organization and role in the ecosystem. Edited by G.C. Carroll and D.T. Wicklow. Marcel Dekker Inc., New York. pp. 563-581.

White, T.J., Bruns, T.D., Lee, S., and Taylor, J.W. 1990. Amplification and direct sequencing of fungal ribosomal RNA genes for phylogenetics. In PCR protocols: a guide to methods and applications. Edited by M.A. Innis, D.H. Gelfand, J.J. Sninsky, and T.J. White. Academic Press, San Diego, Calif. pp. 315-322.

Wright, R.D., and Mooney, H.A. 1965. Substrate-originated distribution of bristlecone pine in the White Mountains of California. Am. Midl. Nat. 73: 257-284. 